\title{
AUTHORSHIP, AUTHORITY AND THE PRODUCTION OF PUBLIC KNOWLEDGE
}

On I8 September 1997, the official opening of 'The Painters of the Wagilag Sisters Story 1937I997' at the National Gallery of Australia saw the outcome of a complex set of negotiations that took place over the preceding months and years between curators and artists, and artists and their custodians, across clan territories occupying the north-eastern half of Arnhem Land. The following texts and images trace part of the process of producing public knowledge, a knowledge that culminated in the events described below.

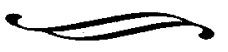

$\mathrm{T}$ he opening is set in the distinctively brutalist architecture of the foyer of the National Gallery of Australia-in its form as distant from the experience of the Yolngu visitors as its function as a nonAboriginal ceremonial space. None of the thirty Yolngu visitors had previously visited this place, a space for them perhaps more evocative of the grandiose public buildings of Darwin - the Casino or the Casuarina shopping mall - than the built environment of North-east Arnhem Land.

For the Yolngu the tiled and concrete foyer of the National Gallery must have appeared as a strikingly exotic and alien frame for the objects and images assembled in the galleries below. Even so, the gallery entrance was made familiar by the close proximity of the conceptual map of Central Arnhem Land represented by the two hundred burial poles of the Aboriginal Memorial. In the first gallery

visible from the foyer the Aboriginal visitors could also find points of familiarity in other examples of their art, even some painted by the visitors themselves, as well as in familiar narratives painted by their close relatives. On the previous day this space had been transformed as the site for the construction and singing of the galmak, the ground design modelled and constructed in sand and eucalyptus leaves which represents the ancestral home of the rainbow serpent at Garimala, a waterhole several hundred kilometers south of Yirrkala. This imposing form provided the focus for the performance of a ritual cleansing ceremony for the nonAboriginal visitors to the opening, allowing outsiders to enter the sacred realm of the forms and images of the narrative of the Wagilag Sisters. 
The sweeping implications of the production of this image of the galmak are captured in the straightforward poetics of the speech of Dula Ngurruwutthun, printed below. Spoken in Munyuku language, his words were certainly a response to his perception of the high status of the occasion. However, for most of the audience the language barrier emphasised the intercultural character of the event. Dula's words were not so much in dialogue with other speakers as a performance in themselves, one event in a sequence that culminated in the opening. He addressed the audience of several hundred people on equal terms: 'this is our way of showing appreciation for your acceptance of our culture, so through this, you will learn to understand and respect our culture...' Of the non-Aboriginal participants in this event, it was the Governor General of Australia, Sir William Deane, who had been specifically nominated to open the exhibition by the elder statesmen of Arnhem Land. For the Yolngu he was identified as the most prominent non-Aboriginal authority prepared to argue for a greater recognition of the needs of Aboriginal Australia. He called for a 'crusade for true reconciliation', a phrase which has echoed ever since in the political debates around Native Title and the Wik case.

As the most senior ritual leader of the Yirritja moiety in East Arnhem Land, Dula revealed in his speech an assumption of good faith on the part of his nonAboriginal hosts. His expectation was that this event would be closely connected to the objective of reconciliation, and that it was his responsibility to ensure that the role and actions of the Yolngu were properly understood in that context. Their display of ritual responsibilities was a demonstration of their expectation of reciprocity and a changing perception of the potential of such interactions between non-Aboriginal and Aboriginal Australians. For the Yolngu, responsibility lies on both sides.

The climax of the opening ceremony was the implanting by the Governor General of matawirr', the lightning-tongue of the ancestral serpent, at the head of the ground design. This painted and feathered object was brought to Canberra in secret, and only revealed to the curators a short time before the event took place. After the exhibition, it was returned to Yirrkala for safe-keeping.

The orchestration of the speeches, songs, smoking business, and the implanting of the matawirr' was devised to provide the appropriate form for the opening of the exhibition. Each participant (including the several non-Aboriginal speakers) was part of a sequence of events, which was, itself, the culmination of a larger sequence that had been in development for over the previous nine years. While the various events in this larger sequence were not pre-ordained, the extent to which they constituted a discourse between the Yolngu world and the non-Aboriginal institution of the Gallery was dependent 


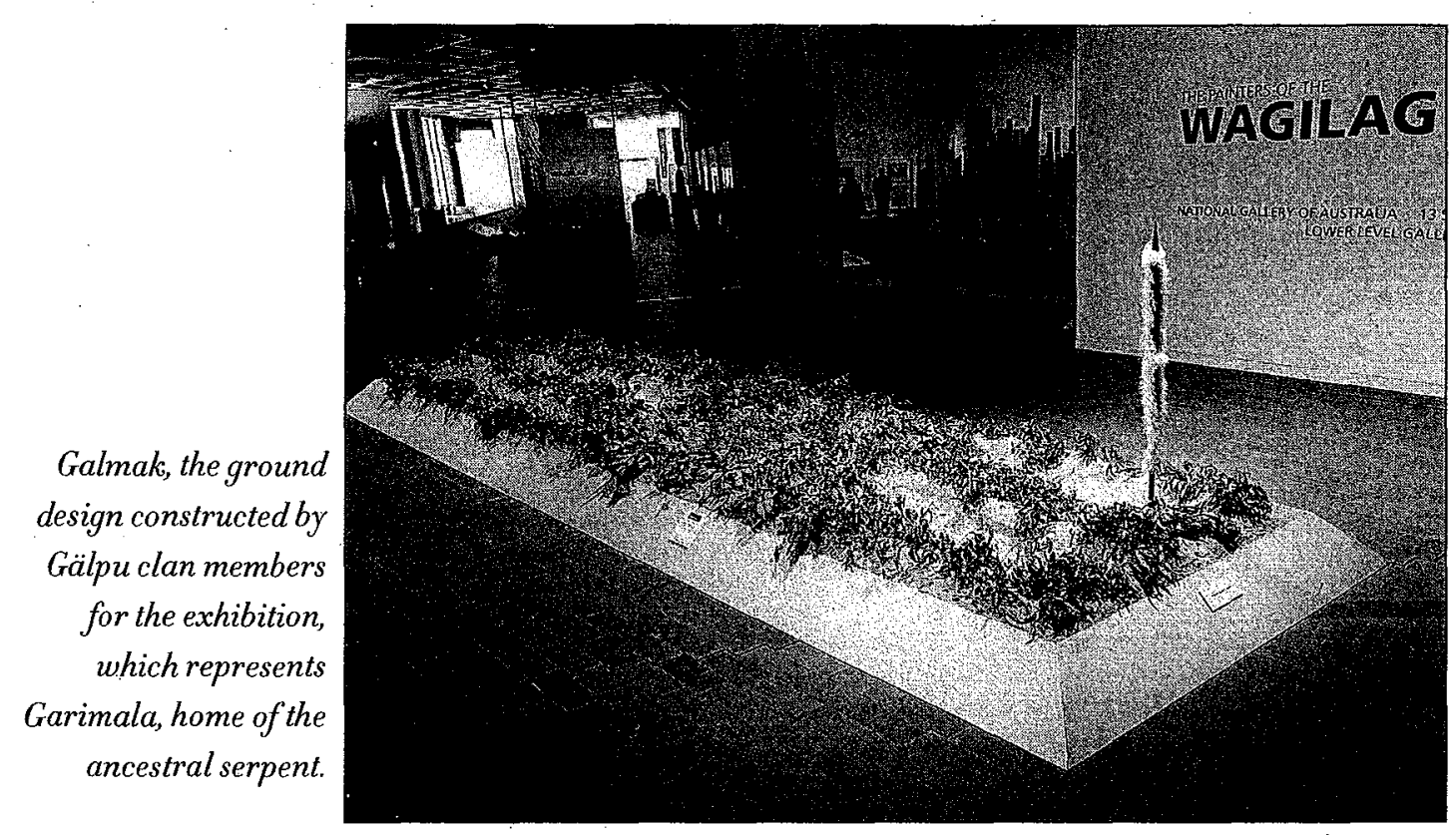

on the necessity of each event effecting a resolution or settlement through an appropriate demonstration of authority.

Such manifestations of 'public knowledge', involving the determination of the form and structure of the performance of ceremony, is a matter of daily discourse in Yolngu society. What was at stake in this instance-. unprecedented in its scale and in the continuity of its historical scope-was the precise determination of the degree to which knowledge was to be demonstrated, revealed, or restricted within this discourse of authorship and authority. The settlement of each event was dependent on such demonstrations of responsibility, and it was necessary for the fine distinction between artist and custodian to be played out a hundred times in the approval of texts, the structure of their representation, the structure of the display, and the structure of events associated with the exhibition.

In suggesting this focus on the sequence of events, I find myself endorsing Strathern's critique of Sahlins, insofar as she proposes a way of recognising an indigenous 'ethnohistory', rather than imposing an interpretative structure: 'we might have to seek out the counterpart of our systematising endeavours in people's artefacts and performances, in the images they strive to convey, and thereby how they present the effects of social action to themselves.' How this view is relevant to my account of the developing negotiations that led to the opening ceremony, is illustrated by one episode which demonstrates how decisively the Yolngu 
participants exercised their authority, and took control of the course of events.

On the Igth April, I997 Sophie Creighton and I visited Gunyangara to meet Djalu Gurruwiwi and other members of the Gälpu clan to seek final permissions for the inclusion of a painting by Djalu and the deceased artist Mithinari in the exhibition. By good fortune, Mithinari's eldest son, Andy Waytjuku, a senior songman Alfred Gurrutjiri and other members of the Gälpu were at Gunyangara at the same time, and gathered around to study the prototype of the catalogue that was presented to them. With permission, Sophie videotaped the interview. In describing the Gälpu relationship to other clans and other parts of the story, and stimulated by the symbolism of the Mithinari painting (which depicts the 'conference of sniakes', a key event in the ancestral narrative), Andy Waytjuku used the metaphor of 'bridging' to describe his perception of their role: 'When you see Mandawuy [Mandawuy Yunupingu, the ceremonial leader as well as the lead singer for Yothu Yindi], he's bridging, building the bridges... We've got clapsticks, [but] he's got all the new technology, all that, bridging this reconciliation to both worlds. Aboriginal society taking it up into white society, this one, [here he points at the image of the snake] this one, Wititj.'

At that moment, suddenly, the Yolngu took control of the situation. They suggested that they would sing the stories contained in the paintings, and that we would videotape the song cycle, and carry it back to Central Arnhem Land to Albert Djiwada, the senior member of the Liyagalawumirr. This symbolic exchange, facilitated by our intervention with the necessary technology, ultimately led to the Gälpu playing a key diplomatic role in the complex negotiations that followed, and subsequently their being given the responsibility for the production of the galmak for the opening ceremony.

Thus Strathern's conception of an event as performative, as a virtual artefact, concerned with its effects and agency, seems particularly appropriate to this discussion. As she observes, 'events are often seen in progression, one following another. An event as performance is known by its effect: it is understood in terms of what it contains, the forms that [it] conceals or reveals, registered in the actions of those who witness it.' ${ }^{2}$ Here, in the months and years preceding the opening ceremony, is to be found an example of the distinctively Yolngu world view and cosmology that pervades every aspect of the installation of the exhibition, in both its performative and literal sense.

In the Eurocentric context of the art gallery, the authority of the individual artist is always given priority. However, for the Yolngu artist a complex of separate roles around the nexus between authorship and authority must be repeatedly renegotiated and publicly affirmed. As the agent of communally restricted knowledge, the artist gives expression to the narratives which are each artist's ancestral inheritance, 
simultaneously bringing alive the agency of the related ancestral beings and the significance of their places of origin.

For these events to take place at all, the artists and their custodians had to be content that the discussions held between themselves and the curators of the exhibition (Wally Caruana, Djon Mundine and myself) allowed for the proper recognition in all matters of detail in the form and structure of the exhibition.

On-the-ground experience, extended fieldwork, and multiple visits to Arnhem Land by the curators had provided the opportunity for negotiations between the artists and their custodians, between the clan groups involved, and through a sequence of preliminary diplomatic exchanges in such different forms as videotaped song cycles and summit meetings involving all the key participants.

The artists in the exhibition come predominantly from the five clans with landowning rights to the different elements of the Wagilag Sisters storyGälpu, Rirratjingu, Marrakulu, Wagilag and Liyagalawumirr. Their clan territories form five-sixths of a circle from the Wessel Islands at the north-eastern tip of Arnhem Land to the Woolen River to the east of Ramingining.

ه Three weeks after the opening, Djon Mundine's talk (at the 'Same But Different: Exhibiting Indigenous Art' Colloquium sponsored by the Centre for Cross-cultural Research and the National Gallery) described the centrality of one figure, the late Paddy Dhatangu, who, as the supreme Dhuwa moiety ritual leader, had been instrumental in the early development and approval of the exhibition. In his talk, Djon speaks with quiet passion and emotion about his long-term involvement with the project as art advisor at Ramingining, and indirectly through other projects as one of the most innovative curators of indigenous art in Australia.

Following Paddy's death in 1993 it was the younger artists and custodians such as Albert Djiwada, Joe Djembungu, Trevor Djarrakaykay and, from the east, Djalu Gurruwiwi and Gawirrin Gumana, who assumed the various responsibilities for the events that were to take place in Canberra. Only in the last stages were other senior ritual leaders and songmen like Dula Ngurruwutthun, Alfred Gurritjiri and Andy Waytjuku more directly involved, contributing to the authoritative resolution of the final sequence of events. And finally, linguists such as Ronnie Barramala and Ngalawurr Mununggurr assisted in crucial explanatory and translation roles.

While it was the assembly of paintings and objects which conveyed the strength of this painting tradition to most of the visitors to the exhibition, extracts from three speeches reprinted here reveal the high order of significance the participants accorded to the events which took place during the culminating ceremony at the National Gallery of Australia. 
Nigel Lendon is Reader in Visual Arts at the ANU Canberra School of Art. He was guest curator of the exhibition, together with Wally Caruana, Senior Curator of AboriginalArt at the NGA and Djon Mundine, Senior Curator of Aboriginal Art at the National Museum of Australia, and with Albert Djiwada as senior indigenous consultant. Sophie Creighton is a doctoral candidate in Anthropology at the $A N U$ and was employed by the National Gallery as a research assistant.

\section{NOTES}

' Strathern, Marilyn, 1990. 'Artefacts of History: events and the interpretation of imageso', in J. Siikala (ed.), Culture and History in the Pacific, 24-44, p. 28. Transactions of the Finnish Anthropological Society, 27. The Finnish Anthropological Society, Helsinki, Finland.

${ }^{2}$ Strathern,'Artefacts of History ...', p. 28-29. 
'... and not to push each other aside'

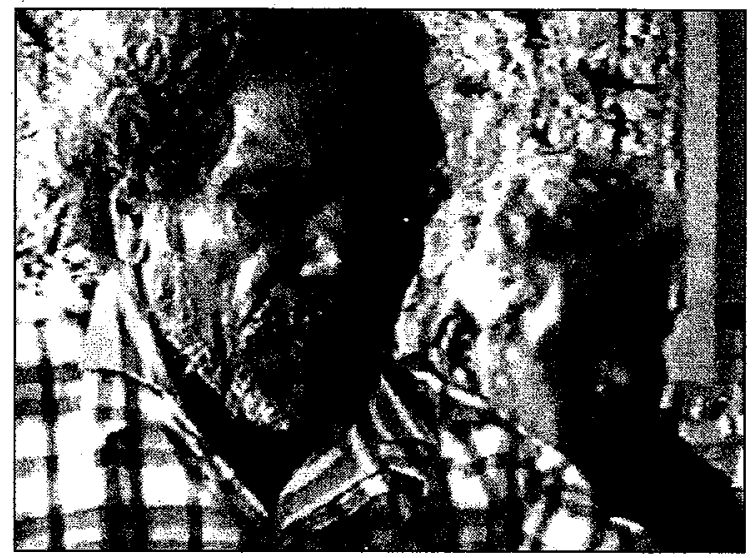

Dula Ngurruwutthun, senior Yirritja ritual leader for North-east Arnhem land, and Andy Waytjuku, son of Mithinari, discuss the arrangements for the opening of the exhibition at the National Gallery of Australia.

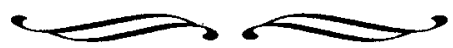

Yo nhumalanggu dhiyaku wurrapandawu walalanggu, luku-nherranmina dhuwala gandawyun yukurra Galmak, bukmakku märr-ngamathinyara nhumalanggu milkungala, märr nhuma yurru dharangan nhaltjan nhuma yurru dhiyanguy malay Balanday Yolngunha liya ga rom yurru nhuma dharangan.

Nhaltjan nganapurru nhumalanha dhiyanguyi rom dhu nguringiyi ngäthilinguyu Yirralkay ga Gutuy.

Ga nganapurru nhumalanggu märr-ngamathinyara wekamayi ga rungiyinyamarama djalkiri ngunhiyi bili Yolnguwala nhanukiyingala rom malanha. Märr ngayi yurru yaka djarrpi'yirri ngunhala bäyma nganapurrunggala Yolnguwala, ga nhokala Balandawala. Yurru dhunupa yana ga galki'kalki, yaka likandhu-ngurrkanhamirri ga bäyngu.
For you non-Aboriginal people, we have set our foundation, here lies the image of Galmak [home of the rainbow serpent]. Embedded in this are our religion, beliefs and values, This is our way of showing appreciation for your acceptance of our culture, so through this, you will learn to understand and respect our worldview, based on the past and coming from our roots.

We appreciate this opportunity to be able to share our culture with you, for this will only strengthen and empower all of us.

So there should be no misunderstanding between us Yolngu people and you Balanda. But to work together to have a better understanding, and not to push each other aside.

Speech by Dula Ngurruwutthun, the senior ritual leader of the Yirritja moiety in East Arnhem Land, translated from Munyuku language by Ngalawurr Mununggurr. 
'... a crusade for true reconciliation'

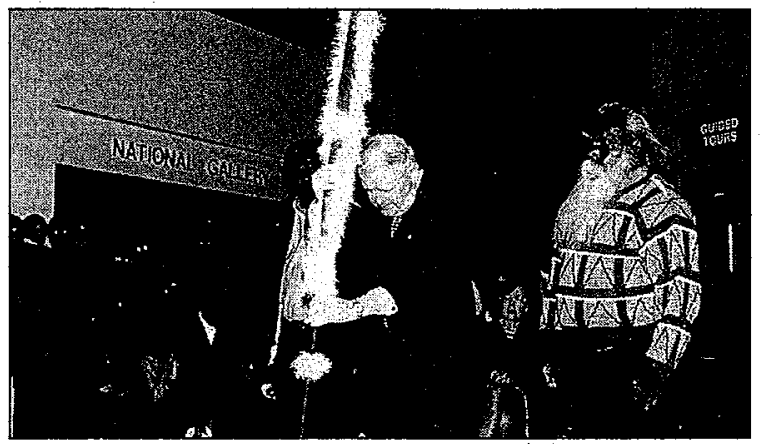

Sir William Deane is instructed in the implanting of matawirr', the lightning-tongue of the ancestral serpent, by Gawarrin Gumana.

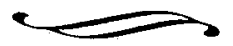

The ancestral events depicted in the exhibition's paintings--involving Wititj the great Olive Python and the two sisters of the Wagilag clan-are dramatic and powerful. The creation story, of which those events form part, recounts the evolution and encounter between human and animal ancestors who explain and make sense of the world and its creative forces. Among other things, the story heralds the arrival of the first monsoon season and forms the basis both of one of the major ceremonial cycles of Arnhem Land, specifically of the inland freshwater country, and of cultural and fundamental religious beliefs and rules of conduct. Indeed, the pictorial narrative of the two Wagilag Sisters and their journey and their ordeals documents the foundation of the laws of social and ritual behaviour, in particular the rules relating to marriage, and inspires laws relating to authority, kinship, territory and custodial responsibility. It reaches from the ancient
Dreamtime to govern the present and to influence and mould the future.

The exhibition has been put together over a period of seven years. It was only made possible by close co-operation and consultation between the curators, the artists and the tribal owners, elders and custodians. The fragility of the medium of eucalyptus bark has in the past militated against the display of many of the finest works of Aboriginal art. The effect of that and of the fact that some of the most important works in the exhibition have come from overseas is that this is the first time that anyone, including the present Aboriginal owners and custodians, has seen the works displayed in anything like their present scope and overall quality. The exhibition provides a wonderful insight into the transmission of important cultural and artistic traditions from one generation to the next, preserving, renewing and adapting knowledge and 
beliefs of the past while casting a light on their relevance to the present. It traces the development of a specific bark painting tradition or genre over six decades and four generations of artists. The first ceremonial leader and artist in the exhibition, Yilkari Kitani, was apparently born in $\mathrm{r} 8 \mathrm{gr}$. He painted at a time when outside influences were minimal. The exhibition reflects the development of the artistic traditions of the peoples of Arnhem Land from the time of his work to the present day. In short, the exhibition is at least one of the most important exhibitions of Aboriginal art ever staged in this country. Its works, in their quality and their comprehensiveness, constitute a unique and coherent tour de force of our indigenous culture. Its assembly and its staging are a triumph of curatorial dedication, skill and achievement.

That being so, tonight is a time of celebration for us all. A celebration of artistic and curatorial achievement. A celebration of indigenous tradition and culture.

And a celebration of learning and understanding. No one who visits this exhibition and is prepared to see, to listen and to learn will be unaffected by the images which it projects. These images reach back over the millennia-perhaps sixty of them--to the earliest days of the indigenous peoples of our land and to the ultimate origins of their ancestral religions, cultures and laws. On the other hand, no one of sensitivity who sees this exhibition and absorbs what it depicts and teaches can fail to be conscious of the wider overall history of dispossession and oppression of the indigenous people in so many other areas of our continent during the 200 years that have elapsed since the arrival of the first European migrants. And no caring Australian can fail to be saddened by the awful contrast between what has been in so many parts of our country and what might have been:

Those of us--both indigenous and nonindigenous - who are now joined together in a crusade for true reconciliation all know that we will not succeed until our nation has properly addressed and made significant progress towards resolving the current plight of the Aboriginal peoples in relation to practical things such as health, education, employment, and living conditions. And how could it be otherwise in a context where the gap between the average life expectancy of an Aborigine and that of a non-Aborigine is almost twenty years and actually widening and where Aborigines are dying from particular diseases at rates up to seven times or more those of non-Aborigines? Clearly, we will not achieve reconciliation until we reach the stage where it can be seen that we are at least approaching the position where the life expectancy and future prospects of an Aboriginal baby are in the same realm of discourse as those of a non-Aboriginal one. But, equally clearly, we have no real prospect of reaching that stage until we also effectively address the terrible problems of the spirit as well as 
those of the body - the present effects on the spirit and on the self-esteem of Australia's indigenous peoples of all that has been threatened, all that has happened, all that has been taken and all that has been destroyed during the two centuries and more that have passed since the arrival of the First Fleet in 1788 .

It is in that context that I see this exhibition as having an importance that transcends both its immediate impact and the ancestral regions of Central and East Arnhem Land. An exhibition such as this enables those Australians who directly view it to enter one of the ancient, and in a sense timeless, Aboriginal worlds of our continent. But it also has the potential to reach out, through and beyond those who directly view it, to influence national perceptions and national attitudes. And it not only projects the artistic achievements and the traditional beliefs of the Arnhem Land artists and their people. It is a wonderful manifestation of Aboriginal art and culture which has the potential to be a positive influence towards restoring and sustaining the spirit and self-esteem of the indigenous peoples of our country as a whole. Hopefully, the exhibition will directly and indirectly affect and influence non-indigenous and indigenous Australians generally in those ways. If it does, it will, of itself, represent a significant step along the difficult road towards true reconciliation between our nation and the indigenous peoples who constitute such an important part of it.

Extract from the address by Sir William Deane, Governor General of the Commonwealth of Australia. 


\section{'Everything in life is interlocked ...'}

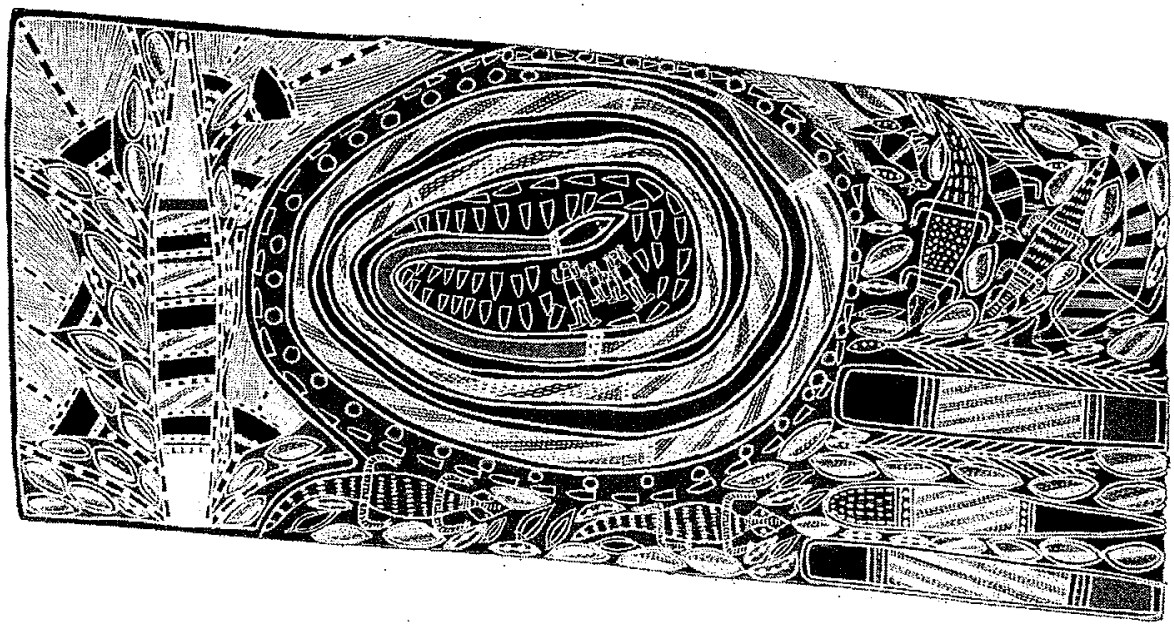

Paddy Dhathangu, Liyagalawumirr/Malimali (with Dorothy Djukulul) 'The Wagilag Sisters Story', rg 3, Collection, National Gallery of Australia.

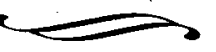

In my own practice one of the things that I have tried to avoid is to see Aboriginal art purely in religious terms, because people always, certainly in the art establishment, have then been able to 'bag' Aboriginal art, or put it in a particular context of, "This is a Dreamtime story'. People always ask, 'What's the Dreamtime story of this thing?' However, in this case, with the study that is represented here-in the way that we have gathered together a number of artworks over at least four generations - -we've tried to get people to look at things in more formal ways. It is interesting, however, that we still can't get people like Giles Autywho wrote very positive articles about the exhibition-they still can't quite get away from the religious experience of it.

Whereas in actual fact we are trying to get people to look at how interestingly the paintings are constructed, how their representation has evolved, how relationships between particular artists have evolved, and how these real human beings have expressed themselves.

Within Aboriginal society, such forms of self-expression, which of course represents in itself some form of group consensus, group expression is not only an ability that people carry; it is actually a responsibility. It is a responsibility that everyone has to bear in that sense. So like with Wally Bell, our friend here from the Ngunnawal people, who has come here to represent them today, the responsibility is always thrust upon you to do public things and to try to create positive images, to create intelligence, to be happy. It is a sign of mental health to do these things.

The thing about the Wagilag Sisters story, it is very interesting in many ways because it involves the two moieties, it has many 
basic Aboriginal concepts in it. Although it is a Dhuwa story, like the Yin and Yangyou can't have it without the involvement, the cooperation of the opposite moiety. So everything is locked together. Everything in life is interlocked, so that whatever you do there is a check and a balance on it, that you have to involve other people.

In one sense, although it is a Dhuwa ceremony, Yirritja people are allowed to sing in this ceremony. It is one of the few ceremonies where that can happen. Usually Dhuwa ceremonies are only sung by Dhuwa people. In this sense this has almost like a Christian feel to it: it talks about one people, it talks about people coming together, from many distant places, to take part in this. It is about how all things interrelate to each other.

The interesting thing in putting the show together, in many ways, is about how most of its ceremonial enactment is actually what is called secret-sacred. In white society, of course, this practically doesn't exist. You can get shots of Elle

McPherson's honeymoon on TV or whatever-nothing is secret-sacred. In Yolngu society there are things that are particularly related to women, so women hold their own ceremony, where men and children aren't allowed to go to. The men hold their ceremony, where women and children aren't allowed to go to. They hold them both at the same time. So it has this thing of male and female seen equally.

In many ways it is an interesting thing that most of this whole story is re-enacted in an elaborate ceremonial cycle we could never hope to actually visualise. In fact, you could never visualise such an experience. However, in showing these paintings, we are able to reveal the public dimension of such things. This is a visual arts place; this is what Yolngu people are showing to you. We have alluded to how people want to share and show people the importance of their culture and how important it is to care for the land-how to care for the environment; how to care for the land, care for the country and look after things.

So this exhibition is very important in that sense. If it does even have the spiritual feeling that Giles Auty received, if that can affect you in some way, I think that is quite a good thing. It is a really good thing.

I think the other thing that you see here, which is even more important-and it is in the catalogue--is that we don't only handle the religiousness, the sacred nature of it in this way. You will find we try to cover in the essays the idea of the development, the skills of these people in draftsmanship, their compositional form, their construction of these paintings, trying to show something that is secretsacred without showing it - to show you the invisible, to hide the visible.

The other thing we have really stressed in this is to also make you realise that these artists are very real human beings. We are not some sort of noble savage. We are like Shylock-we do bleed. We are real human beings. So we do not want tokenisms, we want real land rights. We want things like 
that. We want justice, we want physical things. We want real recognition. And we want constructive criticism of the art, not platitudes and tokenisms.

So we have tried to do that in the catalogue and in the way the exhibition is laid out, so that you'll actually see a body of work by a particular artist, you can see a body of work of father and son, father and daughter, grandfather and grandson, and so on down the ages. You can see people that are distant, at 500 miles distance between each other, painting the same subject in their own style.

Within the catalogue we have enabled Aboriginal voices to speak. Over half the essays written are by Aboriginal contributors, and by the artists themselves. It is not done in a tokenistic way. These people are very sophisticated people. In the case of the Yirrkala people, they most probably travel to more places in the world than any of us, and have shaken hands with more dignitaries and presidents than any of you ever will. So they are not unsophisticated people, they are not unaware of where their art goes, they are not unaware of what they are trying to get across and the message they are trying to get across.

That sort of theme, which I really love, is in the catalogue. So you actually read the autobiographical material-people talking about their own paintings, talking about their own experiences, talking about their use of colour, talking about the way they draw, about what they are trying to say.
I think that that sort of thing is really what is missing in previous discourses - the fact that these are very human people. They are very much alive today. They did play left forward for Milingimbi United. They do live very much in the here and now.

To that end we have had a large number of artists actually come to the exhibition. They were involved in the hang of the show and so on. We wanted people to be here to take part and also enjoy the event as much as we did. It is unfortunate that we could not have people here today, but that was because of circumstances beyond our control.

I can't stress too much the historical importance of how this has come together most probably for the first time. We have brought these artworks back from overseas, from all around the world, and it is interesting in fact where they have ended up, in places in Europe, the United States and various places in Australia - in very peculiar places, quite often, and sometimes rescued from garages and people's attics.

I only want to say one other thing, that my involvement with the Wagilag Sisters came about through my relationship with one man, Paddy Dhathangu, who I spent quite a considerable time with in Ramingining and has a core body of work within the exhibition. In the early 8 os he completed a series of paintings, which we call single-subject paintings, around the Wagilag Sisters story. 
At the time, he was the senior traditional owner of the Wagilag Sisters story, which means he was the senior singer, he was the senior organiser for things to do with the Wagilag Sisters rituals, the stories and the paintings. He happened to be our nextdoor neighbour, just by accident. He kept a house across the road from us and quite often came and visited. He was very used to talking to outside people, he was very used to talking in many ways. He travelled around the Territory during the Second World War; he had spoken to many Balanda people, many outside people.

He had a particular charm and a particular grace. And there were other people like him, and lots of people who come to this society talk about meeting special people, and that is why I called my catalogue essay 'Meetings with Remarkable Men and Women', as they are the people that were particularly remarkable people. Although they had never left the Northern Territory, even, they had a level of sophistication which was pretty astounding, and a human quality of relating to people that you could see why they could organise thousands of people into religious ceremonies from an area of something like about 10,000 square miles; and how they were able to maintain this religious practice and the culture they were making judgments and talking about.

So this person taught me lots of things. It was very difficult, actually, to take part in this exhibition, in many ways, because the whole thing was so personal to me. I didn't know how I would ever actually put this exhibition on or take part in it; it just became too personal for me and I tried to stay away from it very much, because the memory is very painful. $\propto$

Extract of a talk by Djon Mundine, Senior Curator of AboriginalArt, National Museum of Australia, at the conference Same but Different: Exhibiting Indigenous Art' . 